\title{
Drinking Water Toxicity of Sodium Fluoride in Steroid Producing Glands and Antioxidant Ascorbate Defense System in Albino Rats (Rattus norvegicus)
}

Priyanka Mehta ${ }^{1 *}$ and Kunwar Bahadur Singh ${ }^{2}$

${ }^{1}$ Guest Lecturer Department of Animal Science, M.J.P. R. University, Bareilly (U.P) India

${ }^{2}$ Prof. Department of Animal science, M.J.P.R. University, Bareilly (U.P) India

\begin{abstract}
This investigation examined the reproductive toxic effects and oxidative stress of sodium fluoride $(\mathrm{NaF})$ in male albino rats (Rattus norvegicus). The rats received acute doses of NaF as $0.5 \mathrm{ppm}, 200 \mathrm{ppm}$ and $500 \mathrm{ppm}$ through drinking water for 15 days. Additionally $10 \mathrm{mg}$ ascorbate was also supplemented after $\mathrm{NaF}$ treatment as an antidote. The dose $0.5 \mathrm{ppm}$ was ineffective and $500 \mathrm{ppm}$ was fatal after 4 days onwards. A significant decrease in ascorbate content of liver and increase in cholesterol content of liver and testes after 200 ppm NaF-15 days treatment was examined but their level from adrenals did not change significantly. Histological studies of testes in these animals indicated atrophy of steroidogenic cells. Almost similar results were obtained when ascorbate was supplemented as an antidote.
\end{abstract}

Keywords: Sodium fluoride toxicity; Steroid producing glands; Cholesterol; Ascorbate; Mammal

\section{Introduction}

Sodium fluoride $(\mathrm{NaF})$, a well known water pollutant is important throughout the world, including India. The high percentage of fluoride in drinking water of contaminated areas exerts adverse effects on human beings and other vertebrate species $[1,2]$. The normal content of fluoride in drinking water should be under $5 \mathrm{ppm}$. The most obvious early toxic effects of fluoride in humans are dental and skeletal fluorosis, which are endemic in areas with elevated exposure to fluoride [3]. Sodium fluoride mainly exerts its adverse effects on soft tissues, including blood, brain, liver and eyes $[3,4]$. NaF is known to cross the cell membranes and to soft tissues and interfere with their normal metabolic activities $[5,6]$. It causes oxidative stress, enhances lipid per oxidation in the R.B.Cs, brain, liver and decreases activity of antioxidant enzymes i.e. glutathione (GSH), superoxide dismutase (SOD) in fluorosis patients [7,8]. Further, NaF- toxicity in drinking water in contaminated areas causes impairment of fertility in many vertebrate species including human beings $[9,10]$. NaF- exposure, at the dose available in drinking water in contaminated areas, led to inhibition of testicular gametogenesis and steroidogenesis in association with oxidative stress in and male sex organs though they are protected significantly by dietary agents like Vitamin-E and calcium $[11,12]$. In some cases administration of ascorbate and calcium brought about significant recovery of fluoride-induced effects. Recently, Podder et al. [13] reported genotoxic effects of $\mathrm{NaF}$ in drinking water on mouse bone marrow cells. Moreover, according to Zhou et al. [14] NaF- acts as a specific inhibitor of protein synthesis in rabbits.

There are many reports on Fluoride -induced toxicity in organs like liver, kidney and bone marrow but very few on steroid producing tissues and also the role of ascorbate as an antioxidant, particularly in mammals. Thus, the present investigation was aimed to find out toxicity of sodium fluoride in adult male albino rats weighing 120-160gm after ingestion of certain doses of sodium fluoride in their drinking water for one or two weeks and to reflect its impact on antioxidant ascorbate status (from liver and adrenals) and on male fertility. The route chosen in this study for exposure to $\mathrm{NaF}$ via drinking water to mimic human exposure. An additional amount of ascorbate $1 \mathrm{ml}-10 \mathrm{mg}$ daily for 15 days was also provided intramuscularly to find out whether ascorbate supplementation is sufficient to detoxify the Fluoride - toxicity or not.

\section{Material and Methods}

Total 50 adult male albino rats weighing 120-160 gms were used in the present investigation. All the animals were fed on a standard diet of soaked grams, green vegetables, wheat bread and drinking water was provided ad libitum. The animals were divided into five groups, subjected to the following treatments:

Group I: 10 animals, untreated control.

Group II: 10 animals, received $0.5 \mathrm{ppm} \mathrm{NaF}$ in drinking water for 15 days.

Group III: 20 animals, received 200 ppm NaF in drinking water for 15 days.

Group IV: 10 animals from this group III received $1 \mathrm{ml}-10 \mathrm{mg}$ ascorbate daily intramuscularly for another 15 days.

Group V: 10 animals, received $500 \mathrm{ppm} \mathrm{NaF}$ in drinking water for 15 days.

After 15 days of treatment, all the animals were sacrificed and the desired tissues (liver, adrenals and testes) were immediately taken out and kept in their respective media for biochemical and histological studies. Biochemical analysis of asorbate and cholesterol through UVVIS spectrophotometer $[15,16]$. Histological studies include routine

*Corresponding author: Priyanka Mehta, Udit-36A, Mahanagar Colony, Part one, Pilibheet bye pass Road, Bareilly (U.P) 243006, India, E-mail: pmeh_sai@yahoo.co.in

Received November 28, 2011; Accepted February 25, 2012; Published February 27, 2012

Citation: Mehta P, Singh KB (2012) Drinking Water Toxicity of Sodium Fluoride in Steroid Producing Glands and Antioxidant Ascorbate Defense System in Albino Rats (Rattus norvegicus). J Environment Analytic Toxicol 2:123. doi:10.4172/21610525.1000123

Copyright: (C) 2012 Mehta P, et al. This is an open-access article distributed under the terms of the Creative Commons Attribution License, which permits unrestricted use, distribution, and reproduction in any medium, provided the original author and source are credited. 
Citation: Mehta P, Singh KB (2012) Drinking Water Toxicity of Sodium Fluoride in Steroid Producing Glands and Antioxidant Ascorbate Defense System in Albino Rats (Rattus norvegicus). J Environment Analytic Toxicol 2:123. doi:10.4172/2161-0525.1000123

sectioning of adrenals and testes, preparation of permanent slides and their analysis under microscope.

\section{Results}

- Behavioural changes in animals

- Change in their body weights

- Change in bio concentration of ascorbate and cholesterol $(\mathrm{mg} / \mathrm{g})$ from respective tissues

- Histological changes in adrenals and testes of these animals

Visual observation of behaviour of animals of different groups was performed. There was no noticeable change in the behaviour in animals of group I and II. However, animals of group III and IV appeared tired, show unwillingness for food and water, blood spots appeared around their eyes and noses. Besides, the incisor teeth appeared relatively whiter as compared to animals of group I and II. The animals of group $\mathrm{V}$ died during experimentation. The body weight of animals of group III and IV were also significantly reduced as compared to animals of group I and II (Table 1).

There was no change in the level of cholesterol and ascorbate from liver, adrenals and testes after 0.5 ppm NaF - 15 day's treatment (group II). A significant decrease in ascorbate (liver) and increase in cholesterol (liver and testes) were noticed after 200 ppm NaF-15 day's treatment (group III). But their level from adrenals did not change significantly. Additional supplementation of $10 \mathrm{mg}$ ascorbate for 15 days was unable to recover any change over sodium fluoride toxicity i.e. there was no biochemical changes in respective tissues (Table-2,3).

No histological change in the structure of adrenals and testes after $0.5 \mathrm{ppm} \mathrm{NaF}$ treatment. A slight atrophy in adrenal cortex and in seminiferous tubules of testes was observed after 200 ppm NaF - 15 day's treatment. Further, ascorbate treatment in this group was unable to overcome these changes. (Figures 1 to 4 ).

\section{Discussion}

Generation of free radicals, lipid peroxidation and altered antioxidant defence system are considered to play an important role in the toxic effects of fluoride [4,17]. High doses of fluoride have repeatedly been found to interfere with the reproductive systems of animals. In another study, sodium fluoride was administered to the rats orally at a daily dose of $10 \mathrm{mg} / \mathrm{kg}$ body weight for 50 days did not cause significant change in the testicular cholesterol levels, indicating that metabolism was not altered and that there was no hypo/hyper cholesterolemic effect.

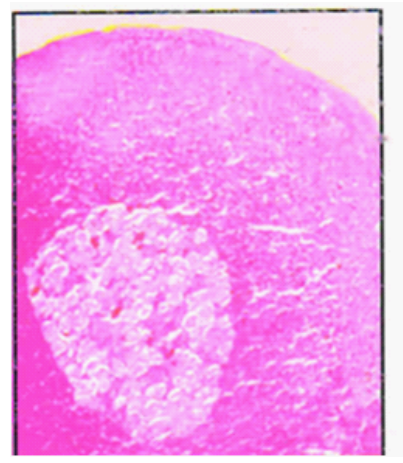

Figure 1: T.S. of adrenal of Group I, normal rats.

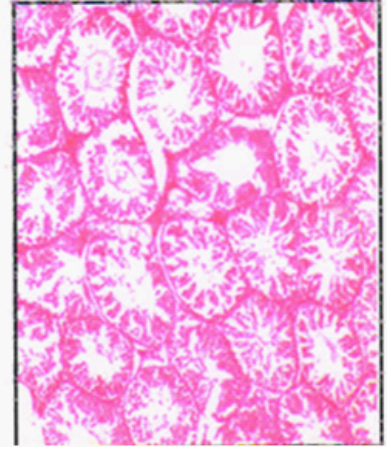

Figure 2: T.S. of testes of group I, normal rats.

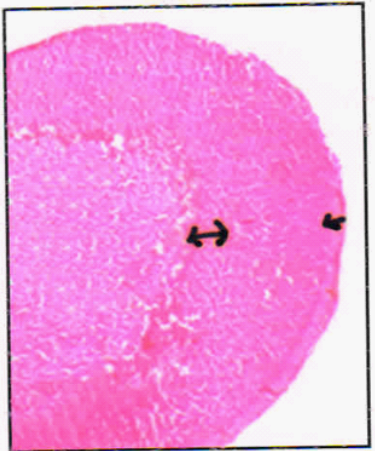

Figure 3: T.S of Adrenal of group III Showing slight atrophy of cortex as Compared to figure $1(\mathrm{X} 140)$

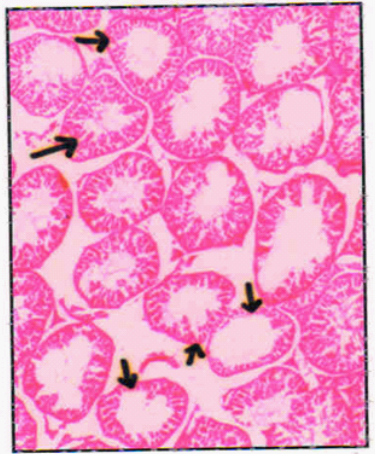

Figure 4: T.S of testes of group III showing atrophy and reduced number of spermatogonial cell (X100).

\begin{tabular}{|l|l|l|l|l|}
\hline Groups & Treatment and Doses & $\begin{array}{l}\text { Initial body } \\
\text { weight }(\mathrm{gm})\end{array}$ & $\begin{array}{l}\text { Body weight } \\
\text { after 15 days }\end{array}$ & $\%$ Change \\
\hline Group I & Untreated control & $136.0 \pm 4.78$ & $135+.5 \pm 2.78$ & 0.37 \\
\hline Group II & $0.5 \mathrm{ppm} \mathrm{NaF}-15$ days & $135.5 \pm 2.0$ & $136.5 \pm 4.63$ & 0.74 \\
\hline Group III & $200 \mathrm{ppm} \mathrm{NaF}-15$ days & $143.0 \pm 3.29$ & $131.11 \pm 2.91$ & 8.31 \\
\hline Group IV & $\begin{array}{l}200 \mathrm{ppm} \mathrm{NaF}-15 \text { days and } \\
10 \mathrm{mg} \text { ascorbate 15 days }\end{array}$ & $142.5 \pm 3.95$ & $132.5 \pm 2.95$ & 7.02 \\
\hline Group V & $\begin{array}{l}500 \mathrm{ppm} \text { NaF- 15 days and } \\
10 \mathrm{mg} \text { ascorbate 15 days }\end{array}$ & $139.8 \pm 1.70$ & Mortality & 0 \\
\hline
\end{tabular}

Values are represented as mean \pm SE

Table 1: Effect of sodium fluoride administration on Body weights (gm). 
Citation: Mehta P, Singh KB (2012) Drinking Water Toxicity of Sodium Fluoride in Steroid Producing Glands and Antioxidant Ascorbate Defense System in Albino Rats (Rattus norvegicus). J Environment Analytic Toxicol 2:123. doi:10.4172/2161-0525.1000123

The degree of testosterone synthesis dependent on fluoride concentration. Testosterone concentration decreased in skeletal fluorosis patients [18]. According to Shivarajashankara [8] plasma ascorbic acid levels of children with skeletal fluorosis were increased. These findings suggest a definite role for ascorbate as an antioxidant and antistress factor in fluoride intoxication.

In the present investigation, $0.5,200$ and $500 \mathrm{ppm}$ sodium fluoride was administered in adult male albino rats via drinking water for 15 days. Additional ascorbate was also supplemented after 200 ppm sodium fluoride treatment for 15 days. There were no significant biochemical and histological changes in group II. The ascorbate content from liver decreased and cholesterol content increased in liver and testes however there was no significant change in the cholesterol content of adrenals (group III and IV) as shown in Table 2 and 3. It indicates that sodium fluoride interferes with metabolic activities of liver. Not any biochemical or histological changes in adrenals indicating that adrenal steroids nothing to do with $\mathrm{NaF}$ toxicity. Increased level of testes cholesterol and atrophy of seminiferous tubules indicating the hyper cholesterolimic effect of $\mathrm{NaF}$ on testes and male fertility. The decrease in the body weights of these animals was due to improper intake of food and water. The similar results were obtained when $1 \mathrm{ml}-10 \mathrm{mg}$ ascorbate supplemented after 200 ppm NaF- 15 day's administration. It means that post ascorbate supplementation was unable to neutralize the effects of $\mathrm{NaF}$ toxicity in albino rats. All of this report is in consistent with earlier reports of Chinoy and Sharma [7], Shivrajashankara [8]. No any observation was possible in group v i.e. $500 \mathrm{ppm} \mathrm{NaF}$ treated rats because they were die one by one with in four days of treatment. The cause of mortality was not established very strongly but it might be due to severe damage of liver cells and other vital organs.

\section{Conclusion}

On the basis of above foregoing accounts, it is clear that $0.5 \mathrm{ppm}$

\begin{tabular}{|l|l|l|l|}
\hline Groups & Treatment \& Doses & Liver & Adrenal \\
\hline Group I & Untreated control & $3.84 \pm 0.03$ & $3.37 \pm 0.04$ \\
\hline Group II & $0.5 \mathrm{ppm} \mathrm{NaF}-15$ days & $3.89 \pm 0.07$ & $3.33 \pm 0.02$ \\
\hline Group III & $200 \mathrm{ppm} \mathrm{NaF}-15$ days & $3.05 \pm 0.05^{\star}$ & $3.34 \pm 0.05$ \\
\hline Group IV & $\begin{array}{l}200 \mathrm{ppm} \mathrm{NaF}-15 \text { days and } 10 \mathrm{mg} \\
\text { ascorbate } 15 \text { days }\end{array}$ & $3.09 \pm 0.05^{\star}$ & $3.35 \pm 0.02$ \\
\hline Group V & $\begin{array}{l}500 \text { ppm NaF- 15 days and 10 } \mathrm{mg} \\
\text { ascorbate 15 days }\end{array}$ & Mortality & Mortality \\
\hline
\end{tabular}

Groups VI, V, IV, III and II were compared with group I $(n=10)$

Values are represented as mean $\pm \mathrm{SE} ;{ }^{*} \mathrm{P}<0.05$; ${ }^{* *} \mathrm{P}<0.001$; ANOVA

Table 2: Effect of sodium fluoride administration on ascorbate content $(\mathrm{mg} / \mathrm{g})$ of liver and adrenal.

\begin{tabular}{|l|l|l|l|l|}
\hline Groups & Treatment and Doses & Liver & Adrenal & Testes \\
\hline Groups I & Untreated control & $27.60 \pm 0.46$ & $54.12 \pm 4.12$ & $22.43 \pm 0.49$ \\
\hline Groups II & $\begin{array}{l}0.5 \mathrm{ppm} \mathrm{NaF}-15 \\
\text { days }\end{array}$ & $27.69 \pm 0.56$ & $50.65 \pm 2.54$ & $22.52 \pm 0.40$ \\
\hline Groups III & $\begin{array}{l}200 \mathrm{ppm} \mathrm{NaF}-15 \\
\text { days }\end{array}$ & $29.35 \pm 0.44$ & $51.17 \pm 2.80$ & $* * 29.67 \pm 0.75$ \\
\hline Groups IV & $\begin{array}{l}200 \mathrm{ppm} \mathrm{NaF}-15 \\
\text { days and 10 mg } \\
\text { ascorbate 15 days }\end{array}$ & $29.14 \pm 0.19$ & $50.72 \pm 1.43$ & $* * 28.98 \pm 0.75$ \\
\hline Groups V & $\begin{array}{l}500 \text { ppm NaF- 15 } \\
\text { days and 10 mg } \\
\text { ascorbate 15 days }\end{array}$ & Mortality & Mortality & Mortality \\
\hline
\end{tabular}

Group VI, V, IV, III and II were compared with group I $(n=10)$

Values are represented as mean $\pm \mathrm{SE},{ }^{* *} \mathrm{P}<0.001$ ANOVA

Table 3: Effect of sodium fluoride administration on cholesterol content $(\mathrm{mg} / \mathrm{g})$ of liver, adrenal and testes.
$\mathrm{NaF}$ - 15 days was not harmful, 200ppm NaF-15 days is complication creating dose and $500 \mathrm{ppm} \mathrm{NaF}$ is fatal for albino rats. The dose $200 \mathrm{ppm}$ $\mathrm{NaF}$ - treatment creates metabolic imbalances in liver and is associated with impairment of male fertility. But adrenal glands appeared to have no significant response against $\mathrm{NaF}$ toxicity and ascorbate treatment did not bring about any alteration as an antidote.

\section{References}

1. Walum E (1998) Acute oral toxicity. Environ Health Perspect 106: 497-503.

2. Kenji A (1997) Re-examination of acute toxicity of fluoride. Fluoride 30: 89-104

3. Singh M (1984) Biochemical and cytological alterations in liver and kidney following experimental fluorosis. Fluoride 17: 81

4. Mullenix PJ, Denbesten PK, Schunior A, Keman WJ (1995) Neurotoxicity of sodium fluoride in rats. Neurotoxicol Teratol 17: 169-177.

5. Freni SC (1994) Exposure to high fluoride concentrations in drinking water is associated with decreased birth rates. J Toxicol Environ Health 42: 109-121.

6. Dabrowaska E, Letko R, Balunowska M (2006) Effect of sodium fluoride on the morphological picture of the rat liver exposed to $\mathrm{NaF}$ in drinking water. Adv Med Sci 1: 91-95.

7. Chinoy NJ, Sharma A (1998) Amelioration of fluoride toxicity by vitamin E and $D$ in reproductive functions of male mice. Fluoride 31: 203-216.

8. Shivarajashankara YM, Shivarajashankara AR, Gopalakrishna BP, Hanumanth RS (2001) Effect of fluoride intoxication on lipid peroxidation and antioxidant defense systems in rats. Fluoride 34: 108-113.

9. Kaur K, Singh J (1980) Histological finding of mice testes following fluoride ingestion. Fluoride 13: 160-162.

10. Hiyasat AS (2000) Reproductive toxic effect of ingestion of sodium fluoride in female rats. Fluoride 33: 279-284.

11. Sarkar SD, Maiti R, Ghosh D (2006) Management of fluoride induced testicula disorders by calcium and vitamin-E co-administration in the albino rat. Reprod Toxicol 22: 606- 612 .

12. Reddy PS, Pushpalatha T, Reddy PS (2007) Suppression of male reproduction in rats after exposure to sodium fluoride during early stages of development. Naturwissenschaften 94: 607-611.

13. Podder S, Chattopadhyay A, Bhattacharya S (2008) In vivo suppression by fluoride of chromosome aberrations induced by mitomycin- $C$ in mouse bone marrow cells. Fluoride 41: 40-43.

14. zhou B, Wang H, Wang J, Zhang J, Yan X, et al. (2009) Effects of malnutrition andsupplemented nutrition on specific immune parameter changes induced by fluoride in rabbits. Fluoride 42: 216-223.

15. Dabrowaski K, Hinterlitner S, Stunnbaoer C, Fiky EIN (1989) Application of a Simultaneous assay of ascorbic acid, dehydroascorbic acid and ascorbic sulphate in biological materials. Aquaculture 72: 295.

16. Washburn KW, Nix D F (1974) A rapid technique for the extraction of yolk cholesterol. Poult Sci 53: 1118-1122.

17. Rezuski R, Chulubek D, Mackoy D (1998) Interactions between fluoride and biological free radical reactions. Fluoride 31: 43-45.

18. Susheela AK, Jethanandani P (1996) Circulating testosterone levels in skeleta fluorosis patients. J Toxicol Clin Toxicol 34: 183-189.

19. Chinoy NJ, Patel PD (2001) Effects of sodium fluoride and aluminium chloride on ovary and uterus of mice and their reversal by some antidotes. Fluoride 34 9-20.

20. Chinoy NJ, Sharma M, Michael M (1993) Beneficial effects of ascorbic acid and calcium on reversal of fluoride toxicity in male rats. Fluoride 26: 45-56.

21. Gosh D (2002) Testicular toxicity in sodium fluoride treated rats associated with oxidative stress. Reproductive Toxicology 16: 385-390.

22. Kour K, Kohl M L, Koul RL (1981) Histological changes in liver following sodium fluoride ingestion. Fluoride 14: 119-123. 
Citation: Mehta P, Singh KB (2012) Drinking Water Toxicity of Sodium Fluoride in Steroid Producing Glands and Antioxidant Ascorbate Defense System in Albino Rats (Rattus norvegicus). J Environment Analytic Toxicol 2:123. doi:10.4172/2161-0525.1000123

Page 4 of 4

23. Machalinska A, Wiszniewska B, Tarasink J, Machalinski B (2002) Morphological effects of sodium fluoride on haematopoietic organs in mice. Fluoride 35: 231 238.

24. Reddy GB, Khandare AL, Reddy PY, Rao GS, Balakrishna N, Srivalli I (2003) Antioxidant defense system and lipid peroxidation in patients with skeletal fluorosis and fluoride-intoxicated rabbits. Toxicol Sci 72: 363-368
25. Shashi I (1990) Fluoride-induced changes in rabbit lens during experimental fluorosis. J Environ Biol 11: 247.

26. Shashi A, Thaper SP (2001) Histopathy of fluoeide induced hepatotoxicity in rabbits. Fluoride 34: 34-42. 